\title{
Analisis Pengaruh Tingkat Bunga, Tingkat Inflasi, Earning Per Share Terhadap Harga Saham PT. Bank Mandiri (persero) Tbk.
}

\author{
DIDI RAHMAT \\ Dosen Tetap Sekolah Tinggi Ilmu Ekonomi "Indonesia” Pontianak
}

\begin{abstract}
In this research, we investigate impact of Inflation Rate, Interes Rate and Earning per Share as independent variable to the PT. Bank Mandiri (persero) Tbk. stock price. We use causality research with multiple regression analysis method to answer the hypothesis. As conclusion that find, all independent variabel have impact significantly to the stock price in $0.78 \%$. In partial, inflation has no impact to the stock price. In other way, interest rate have significantly influence to the stock price. But the influence is negative. EPS fositive have influence significantly to stock price.
\end{abstract}

Key word: Inflation; Interest Rate; EPS; Stock Price

\section{PENDAHULUAN}

Pasar modal adalah salah satu bentuk pasar keuangan, dimana para individuindividu atau badan usaha yang mempunyai kelebihan dana (surplus fund) melakukan investasi dalam surat berharga yang ditawarkan emiten. Aktivitas ini dilakukan pada pasar primer, pasar sekunder dan pasar derivatif. Di sisi lain pasar modal juga merupakan tempat bagi perusahaan yang membutuhkan dana dan menawarkan surat berharga dengan cara melakukan Initial Public Offering (IPO) pada badan otoritas dipasar modal sebagai emiten.

Alat investasi pada pasar primer yang biasa di pilih adalah saham (stock). Pada pasar sekunderpun saham masih merupakan pilihan yang popular dalam berinvestasi. Salah satu surat berharga yang cukup populer diperjualbelikan di pasar modal adalah saham (Tandelilin, 2001:18). Jika dibandingkan dengan investasi pada surat berharga atau sekuritas lainnya saham memungkinkan investor meraih return atau keuntungan lebih besar dalam waktu relatif singkat (high return) meskipun saham juga memiliki sifat high risk dimana suatu saat harga saham bisa menurun dengan cepat. Jadi saham tersebut memiliki karakteristik high risk high return (Manurung, 2003 : 98)

Salah satu aspek penting yang menarik untuk dipahami dalam pasar modal adalah tentang pergerakan naik turunnya harga saham (volatilitas). "Harga saham di bursa efek ditentukan oleh kekuatan permintaan dan penawaran. Pada saat permintaan saham meningkat, maka harga saham tersebut cenderung meningkat. Sebaliknya, pada saat banyak orang menjual saham, maka harga saham cenderung mengalami penurunan " (Anoraga dan Pakarti , 2003: 60). Dalam pasar modal justru adanya harga yang berubah - ubah tersebut menjadikan bursa efek menarik bagi beberapa kalangan pemodal (investor), dimana dengan adanya peningkatan harga saham investor akan memperoleh keuntungan dari selisih penjualan harga saham tersebut (capital gain) meskipun mereka juga dapat menanggung kerugian jika harga saham yang dibeli mengalami penurunan dalam harga jualnya(capital loss). 
Harga saham menunjukkan nilai pasar dari suatu saham. Harga saham biasa yang terjadi di pasar (harga pasar saham) sangat berarti bagi perusahaan karena harga tersebut akan menentukan besarnya nilai perusahaan (Tandelilin, 2001:19). Perkembangan harga saham mencerminkan kekuatan pasar modal dari suatu emiten. Harga saham sangat penting bagi emiten karena dengan adanya peningkatan harga saham maka akan meningkatkan kekayaan para emiten itu sendiri dan pihak investor akan memperoleh tambahan pendapatan yang lebih baik melalui pembagian dividen. Peningkatan harga saham suatu perusahaan menunjukkan bahwa saham tersebut diminati atau memperoleh permintaan yang tinggi oleh pihak investor. Sebaliknya penurunan harga saham menunjukkan bahwa investor mulai kurang tertarik untuk membeli saham perusahaan tersebut.

Perkembangan harga saham di pengaruhi oleh berbagai faktor baik makro ekonomi maupun mikro ekonomi (Samsul, 2006:200). Faktor makro ekonomi adalah faktor-faktor yang mempengaruhi ekonomi secara keseluruhan yang berada di luar perusahaan yang mempunyai pengaruh terhadap kinerja saham maupun perusahaan baik secara langsung maupun tidak langsung, seperti tingkat bunga, tingkat inflasi, kurs valuta asing, peredaran uang, kebijakan pemerintah dan lain - lain, sedangkan faktor mikro ekonomi berada dalam perusahaan itu sendiri antara lain ditunjukkan oleh rasio keuangan perusahaan, seperti laba bersih per saham (Earning per Share/EPS), nilai buku per saham, rasio ekuitas terhadap utang (debt to equity ratio), rasio laba bersih terhadap utang (return on equity) dan lain - lain.

Harga saham akan terpengaruh dengan seketika oleh perubahan faktor makro ekonomi karena para investor lebih cepat bereaksi. Ketika perubahan faktor makro itu terjadi, investor akan mengkalkulasi dampaknya baik positif maupun negatif terhadap kinerja perusahaan, kemudian mengambil keputusan untuk membeli atau menjual saham bersangkutan. Perubahan faktor makro ekonomi yang sering berfluktuasi dan sangat penting di analisa investor sebagai pertimbangan investasi di antaranya perubahan tingkat bunga dan tingkat inflasi.

Perubahan tingkat bunga bisa berdampak positif maupun negatif, ketika tingkat bunga meningkat akan berdampak negatif bagi emiten, karena meningkatkan beban bunga kredit dan menurunkan laba bersih, sehingga laba per saham juga menurun dan akhirnya berakibat turunnya harga saham. Di sisi lain naiknya suku bunga akan menyebabkan investor menjual saham dan mengalihkan dananya untuk menabung dalam deposito, akibatnya harga saham di pasar akan cenderung menurun. Oleh karena itu kenaikan tingkat bunga akan mengakibatkan turunnya harga saham, dan sebaliknya penurunan tingkat bunga akan menaikkan harga saham di pasar.

Inflasi merupakan suatu indikator ekonomi makro yang menggambarkan kenaikan harga barang dan jasa dalam suatu periode tertentu. Tingkat inflasi dapat berpengaruh positif maupun negatif tergantung derajat inflasi itu sendiri. Inflasi yang terlalu tinggi dapat merugikan perekonomian secara keseluruhan, yaitu dapat membuat banyak perusahaan mengalami kebangkrutan karena biaya produksi lebih besar dari peningkatan harga produk. Bagi investor inflasi yang tinggi akan mengurangi pendapatan riil yang diperoleh dari investasinya tersebut, akhirnya berakibat pada jatuhnya harga saham di pasar.

Faktor mikro ekonomi menunjukkan kinerja perusahaan yang tercermin oleh rasio - rasio keuangan, yang tentunya sangat penting diketahui oleh investor dalam melakukan investasi karena akan memberikan dampak terhadap pendapatan yang mereka peroleh dan masa depan dari investasi tersebut. Rasio keuangan yang 
penting diketahui investor sebagai dasar penilaian antara lain, laba bersih per saham (Earning Per Share/EPS), rasio ekuitas terhadap utang (Debt to Equity Ratio) serta rasio laba bersih terhadap utang (Return On Equity/ROE).

Komponen penting pertama yang harus diperhatikan dalam analisa rasio perusahaan adalah Earning Per Share, dimana EPS menunjukkan laba bersih perusahaan yang siap dibagikan bagi semua pemegang saham perusahaan, semakin tinggi EPS berarti semakin besar earning yang akan di terima investor dari investasinya tersebut, sehingga investor akan lebih tertarik untuk membeli saham perusahaan bersangkutan.

Secara empiris permasalahan yang berkaitan dengan kondisi makro dan mikro ekonomi yang mempengaruhi harga saham telah dilakukan oleh peneliti - peneliti sebelumnya. Salah satunya dilakukan oleh Amit Malhotra (2009) melakukan penelitian terhadap bank nasional dan bukan bank dengan Earnings per Share (EPS), Gross Domestic Product (GDP), Consumer Price Indeks(CPI) Interest Rate (INT), Money Supply (MS) sebagai variabel yang mempengaruhi harga saham (stock price). Hasil penelitian menunjukkan untuk kelompok bank EPS, MS dan GDP mempunyai pengaruh positif dan signifikan terhadap harga saham, dengan tingkat signifikan $1 \%$ untuk EPS dan 5\% untuk MS dan GDP, sedangkan CPI dan INT mempunyai pengaruh negatif terhadap harga saham dengan tingkat signifikan 1\%, CPI mempunyai pengaruh signifikan tetapi INT tidak signifikan, sedangkan untuk kelompok bukan bank menghasilkan EPS mempunyai pengaruh positif dan signifikan dengan tingkat signifikan 1\%, MS dan GDP mempunyai pengaruh positif dengan tingkat signifikan 5\% dimana MS mempunyai pengaruh signifikan tetapi GDP tidak signifikan, CPI mempunyai pengaruh negatif tetapi tidak signifikan dan INT mempunyai pengaruh positif tetapi tidak signifikan. Ternyata untuk kedua kelompok EPS merupakan variabel dominan yang mempengaruhi harga saham. Abdurrahman Sadikin (2006) meneliti variabel price earning ratio, market to book value, dividend payout ratio, dividend yield, debt to equity ratio, return on investment, return on equity, kurs, tingkat inflasi, suku bunga deposito sebagai variabel yang mempengaruhi harga saham, dengan melakukan penelitian pada perusahaan manufaktur. Temuan penelitian tersebut menyatakan secara simultan semua variabel berpengaruh terhadap harga saham sebesar $32,1 \%$, sedangkan secara parsial hanya market to book value, debt to equity ratio, kurs, tingkat inflasi dan suku bunga deposito yang berpengaruh signifikan terhadap harga saham

Dari berbagai variabel yang mempengaruhi harga saham tersebut, perlu kiranya bagi investor yang menginvestasikan dananya dipasar modal untuk mengetahui dan menganalisa informasi yang berkenaan dengan faktor -faktor tersebut sebagai pertimbangan dalam keputusan investasi, sehingga dapat digunakan sebagai dasar penaksiran atas harga saham bersangkutan dan mengetahui prospek saham kedepan dalam mengharapkan keuntungan atas investasi tersebut serta memperkecil resiko kerugian, baik yang bersifat mengharapkan penghasilan tetap dari dividen maupun bertujuan untuk memperoleh capital gain.

Seperti diketahui bahwa saham - saham yang diperjualbelikan dalam Bursa Efek Indonesia adalah saham - saham yang berasal dari perusahaan yang telah go public. Salah satu perusahaan emiten yang menjual sahamnya di pasar bursa adalah PT. Bank Mandiri (persero) Tbk., yang bergerak dalam bidang jasa keuangan . Perusahaan ini telah mendaftarkan $40 \%$ dari sahamnya di Bursa Efek Jakarta dan 


\section{INTEGRA Volume III. Januari 2013. ISSN0216-4337}

Bursa Efek Surabaya setelah melakukan Initial Public Offering pada tanggal 14 Juli 2003.

PT. Bank Mandiri (persero) Tbk. merupakan salah satu emiten yang masuk dalam kategori saham blue-chips, yaitu emiten yang mampu menghasilkan pendapatan tinggi dan membagikan dividen tunai. Pada tabel 1 terlihat selama 6 tahun terakhir yaitu periode 2007 sampai dengan 2011 PT. Bank Mandiri (persero) Tbk.telah membagikan dividennya, sebagai berikut :

\section{Tabel 1}

Perkembangan dividen PT. Bank Mandiri (persero) Tbk.

Periode Tahun 2007 sampai dengan 2011

\begin{tabular}{cc}
\hline Tahun & $\begin{array}{c}\text { Cash Dividend } \\
\text { perlembar saham }\end{array}$ \\
\hline 2007 & 186,00 \\
2008 & 88,55 \\
2009 & 19,26 \\
2009 & 19,64 \\
2010 & 120,60 \\
2011 & 104,97 \\
\hline
\end{tabular}

Sumber : Bursa Efek Indonesia (data diolah 2012)

Adapun pergerakan (volatilities) harga saham PT. Bank Mandiri (persero) Tbk, selama tahun 2012 dapat dilihat pada tabel 2 berikut ini:

Tabel. 2

Stock Volatilities PT. Bank Mandiri (persero) Tbk.

Periode tahun 2012

\begin{tabular}{cccc}
\hline \multirow{2}{*}{ Bulan } & \multicolumn{3}{c}{ Closing Price } \\
\cline { 2 - 4 } & High & Low & Close \\
\hline Januari & 7.150 & 6.600 & 6.700 \\
Februari & 6.750 & 6.000 & 6.450 \\
Maret & 6.950 & 6.350 & 6.850 \\
April & 7.400 & 6.800 & 7.400 \\
Mei & 7.450 & 6.650 & 6.900 \\
Juni & 7.350 & 6.550 & 7.200 \\
Juli & 8.300 & 6.850 & 8.300 \\
Agustus & 8.600 & 7.350 & 7.800 \\
September & 8.300 & 7.600 & 8.200 \\
Oktober & 8.400 & 7.900 & 8.250 \\
November & 8.900 & 8.150 & 8.250 \\
Desember & 8.450 & 7.700 & 8.100 \\
\hline
\end{tabular}

Sumber : Bursa Efek Indonesia (data diolah 2012)

Melihat data pada tabel 1, dimana pembagian dividen dibagikan setiap tahun, maka tentunya saham dari PT. Bank Mandiri (persero) Tbk. dapat menarik minat investor, karena mampu memberikan pendapatan yang menarik bagi mereka. Selain itu pada tabel 2 terlihat selama tahun 2012 harga saham perusahaan ini cenderung 
mengalami peningkatan dari harga pembukaan bulan januari sampai harga penutupan di bulan desember.

Berdasarkan model penelitian dan perumusan masalah, maka hipotesis dalam penelitian ini adalah sebagai berikut :

Hipotesis 1 :

Tingkat bunga, tingkat inflasi, Earning Per Share (EPS) secara simultan berpengaruh signifikan terhadap harga saham PT. Bank Mandiri (persero) Tbk.

Hipotesis 2 :

H1 : tingkat Inflasi berpengaruh signifikan terhadap harga saham PT. Bank Mandiri (persero) Tbk.

$\mathrm{H} 2$ : tingkat Bunga berpengaruh signifikan terhadap harga saham PT. Bank Mandiri (persero) Tbk.

H3 : Earning Per Share (EPS) berpengaruh signifikan terhadap harga saham PT.

Bank Mandiri (persero) Tbk.

Hipotesis 3 :

Earnings Per Share (EPS) merupakan variabel dominan dalam mempengaruhi harga saham PT. Bank Mandiri (persero) Tbk.

\section{METODE PENELITIAN}

\section{Metode dan Pendekatan yang digunakan}

Penelitian ini menggunakan metode analisis dokumen (documentary anlysis), dengan pendekatan kuantitatif. Karena menurut Arikunto (2000 : 321) penelitian yang dilakukan terhadap informasi yang di dokumentasikan dalam rekaman, baik gambar, suara, tulisan atau lain - lain bentuk rekaman, biasa dikenal dengan penelitian analisis dokumen.

\section{Unit analisis}

Unit analisis merujuk pada tingkat kesatuan data yang dikumpulkan selama tahap analisis data selanjutnya (Sekaran, 2006 : 173). Jadi unit analisis dalam penelitian ini adalah harga saham, tingkat bunga, tingkat inflasi dan laporan keuangan PT. Bank Mandiri (persero) Tbk.

\section{Teknik Sampling}

Teknik pengambilan sampel yang akan digunakan dalam penelitian ini termasuk dalam kelompok nonprobability sampling, yaitu teknik pengambilan sampel yang tidak memberikan peluang/kesempatan bagi setiap unsur (anggota) populasi untuk dipilih menjadi sampel (Sugiyono, $2007: 77$ ), sedangkan pengambilan sampelnya menggunakan teknik sampling sistematis, yaitu teknik pengambilan sampel berdasarkan urutan dari anggota populasi yang telah diberi nomor urut. Pada penelitian ini laporan keuangan dari PT. Bank Mandiri (persero) Tbk selama periode 10 tahun terakhir yang dijadikan sampel. 


\section{INTEGRA Volume III. Januari 2013. ISSN0216-4337}

\section{Variabel Penelitian}

Variabel yang diteliti dalam penelitian ini adalah sebagai berikut :

1. Variabel Dependen (Y)

Variabel dependen dalam penelitian ini adalah harga saham, yaitu harga per lembar saham biasa yang terjadi dalam kegiatan perdagangan saham di pasar bursa, yang diambil berdasarkan harga penutupan saham PT. Bank Mandiri (persero) Tbk.

2. Variabel Independen

a. Tingkat Inflasi $\left(\mathrm{X}_{1}\right)$

Tingkat suku bunga Sertifikat Bank Indonesia (SBI) yang berlaku yang di tetapkan oleh Bank Indonesia, yang diambil berdasarkan suku bunga untuk jangka waktu tiga bulanan.

b. Tingkat Bunga $\left(\mathrm{X}_{2}\right)$

Inflasi adalah kecenderungan terjadinya peningkatan harga produk - produk secara keseluruhan, karena permintaan atas produk melebihi kapasitas penawaran produknya, sehingga inflasi yang terlalu tinggi akan menyebabkan penurunan daya beli uang (Tandelilin,2001). Tingkat inflasi diambil dari tingkat inflasi data statistik Indonesia, berdasarkan data inflasi dalam triwulan.

c. Earning Per Share (EPS) $\left(\mathrm{X}_{3}\right)$

EPS adalah perbandingan antara laba bersih setelah pajak yang diperoleh emiten dengan jumlah lembar saham yang beredar. Besarnya EPS suatu perusahaan bisa diketahui dari informasi laporan keuangan perusahaan atau berdasarkan laporan neraca dan laporan rugi laba perusahaan. Rasio ini dirumuskan sebagai berikut :

$$
E P S=\frac{\text { Laba bersih setelah bunga dan pajak }}{\text { Jumlah saham beredar }}
$$

\section{Pengumpulan Data}

Jenis data dalam penelitian ini termasuk data kuantitatif, yaitu data yang dinyatakan dalam bentuk angka (Santoso, 2005:4). Dimana data dalam penelitian ini data terdiri dari tingkat bunga, tingkat inflasi,harga saham dan laporan keuangan.

Sumber data yang digunakan dalam penelitian ini adalah data sekunder. Menurut Indiantoro dan Supomo (2002 : 147) data sekunder merupakan sumber data penelitian yang diperoleh peneliti secara tidak langsung melalui media perantara (diperoleh dan dicatat oleh pihak lain).

Data sekunder dari penelitian ini yaitu :

1. Data laporan keuangan PT. Bank Mandiri (persero) Tbk selama periode 2009 sampai dengan 2012.

2. Data sekunder lainnya, yaitu data yang diperoleh melalui publikasi pada majalah, buku-buku, laporan penelitian dan jurnal.

Data sekunder mengenai harga saham didapat melalui situs internet http://finance.yahoo.com, data suku bunga dan inflasi dari situs http://www.bi.go.id/, sedangkan untuk data laporan keuangan diperoleh melalui situs jsx.co.id. 


\section{INTEGRA Volume III. Januari 2013. ISSN0216-4337}

\section{Teknik pengumpulan data}

Menurut Arikunto (2000:134) metode pengumpulan data adalah cara - cara yang dapat digunakan peneliti untuk mengumpulkan data, antara lain melalui angket, wawancara, pengamatan, ujian atau tes dan dokumentasi. Jadi teknik yang sesuai dalam penelitian ini adalah teknik dokumentasi, dengan tipe time series selama periode tahun 2009 sampai dengan 2012.

\section{Teknik Analisis Data}

Berdasarkan kerangka konsep yang telah dijelaskan maka teknik analisis data yang digunakan adalah regresi linear berganda, untuk mencari pengaruh variabel independen terhadap variabel dependennya, baik secara simultan maupun parsial, dengan menggunakan program SPSS versi 18 (Statistical Package for the Social Science). Model regresi linier berganda dirumuskan sebagai berikut :

$$
\mathrm{Y}=\mathrm{b}_{0}+\mathrm{b}_{1} \mathrm{x}_{1}+\mathrm{b}_{2} \mathrm{X}_{2}+\mathrm{b}_{3} \mathrm{x}_{3}+\mu_{\mathrm{i}}
$$

Keterangan :

$\mathrm{Y}=$ Harga Saham

$\mathrm{b}_{0}=$ intercept dari persamaan regresi/konstanta

$\mathrm{b}_{1}, \mathrm{~b}_{2}, \mathrm{~b}_{3}, \mathrm{~b}_{4}, \mathrm{~b}_{5}=$ Koefisien regresi untuk masing - masing variabel

$\mathrm{X}_{1}=$ tingkat Inflasi

$\mathrm{X}_{2}=$ tingkat Bunga

$\mathrm{X}_{3}=$ earning per share (EPS)

$\mu_{\mathrm{i}}=$ standar error/kesalahan penganggu

Untuk mengetahui pengaruh variabel tingkat bunga, tingkat inflasi, earning per share(EPS), terhadap harga saham, dilakukan uji baik secara simultan maupun secara parsial dengan tingkat kepercayaan $95 \%(\alpha=5 \%)$.

Pengujian hipotesis dilakukan secara statistik dengan cara :

a. Uji Signifikan Simultan (Uji Statistik F)

Uji statistik $\mathrm{F}$ digunakan untuk menguji apakah semua variabel bebas yang dimasukkan dalam suatu model memiliki pengaruh secara bersama - sama terhadap variabel terikat. Hipotesis nol (Ho) yang hendak di uji adalah apakah semua parameter dalam model sama dengan nol, atau dirumuskan sebagai berikut:

$\mathrm{H}_{0}: \mathrm{b}_{1}=\mathrm{b}_{2}=\mathrm{b}_{3}=0$ (tidak terdapat pengaruh signifikan secara simultan antara tingkat bunga, tingkat inflasi, earning per share(EPS), terhadap harga saham PT. Bank Mandiri (persero) Tbk)

$\mathrm{H}_{\mathrm{a}}: \mathrm{b}_{1}=\mathrm{b}_{2}=\mathrm{b}_{3} \neq 0$ (terdapat pengaruh signifikan secara simultan antara tingkat bunga, tingkat inflasi, Earning per Share(EPS), terhadap harga saham PT. Bank Mandiri (persero) Tbk)

- Jika $F_{\text {hitung }}<F_{\text {tabel }}$ atau $F_{\text {sig }}>\alpha$ berarti Ho diterima dan Ha ditolak.

- Jika $F_{\text {hitung }}>F_{\text {tabel }}$ atau $F_{\text {sig }}<\alpha$ berarti Ha diterima dan Ho ditolak.

b. Uji Signifikan parameter individual/parsial (Uji Statistik t)

Uji statistik t pada dasarnya menunjukkan seberapa jauh pengaruh satu variabel secara individual terhadap variabel independen. Hipotesis nol (Ho) yang hendak diuji adalah apakah suatu parameter (bi) sama dengan nol, atau dirumuskan sebagai berikut :

$\mathrm{H}_{0}: \mathrm{b}_{1}=0$ : tidak terdapat pengaruh signifikan dari tingkat Inflasi terhadap harga saham PT. Bank Mandiri (persero) Tbk. 


\section{INTEGRA Volume III. Januari 2013. ISSN0216-4337}

$\mathrm{H}_{\mathrm{a}}: \mathrm{b}_{1} \neq 0$ : terdapat pengaruh signifikan dari tingkat inflasi terhadap harga saham PT. Bank Mandiri (persero) Tbk.

$\mathrm{H}_{0}: \mathrm{b}_{2}=0$ : tidak terdapat pengaruh signifikan dari tingkat bunga terhadap harga saham PT. Bank Mandiri (persero) Tbk.

$\mathrm{H}_{\mathrm{a}}: \mathrm{b}_{2} \neq 0$ : terdapat pengaruh signifikan dari tingkat bunga terhadap harga saham PT. Bank Mandiri (persero) Tbk.

$\mathrm{H}_{0}: \mathrm{b}_{3}=0$ : tidak terdapat pengaruh signifikan dari Earning Per Share (EPS) terhadap harga saham PT. Bank Mandiri (persero) Tbk.

$\mathrm{H}_{\mathrm{a}}: \mathrm{b}_{3} \neq 0$ :terdapat pengaruh signifikan dari Earning Per Share (EPS) terhadap harga saham PT. Bank Mandiri (persero) Tbk.

- Jika $t_{\text {hitung }}<t_{\text {tabel }}$ berarti Ho diterima dan Ha ditolak.

- Jika $t_{\text {hitung }}>t_{\text {tabel }}$ berarti Ha diterima dan Ho ditolak.

Berdasarkan uji t yang dilakukan, maka untuk mengetahui variabel dominan yang mempengaruhi harga saham, tolak ukur yang digunakan adalah dengan melihat koefisien beta standart dan korelasi parsial yang paling tinggi.

\section{HASIL ANALISIS DAN PEMBAHASAN}

Dalam menjawab permasalahan dan melakukan uji terhadap hipotesis dari Variabel bebas Tingkat Inflasi (X1), Tingkat Sukubunga (X2) dan Earning Per Share (X3) terhadap variabel terikat Harga Saham (Y), maka digunakan uju statistiuk dengan menggunakan regresi berganda. Dari hasil olah data dengan menggunakan bantuan software SPPS Ver.18, diperoleh kesimpulan sebagai berikut:

Tabel 3

Hasil Olah Data Statistik

\begin{tabular}{|c|c|c|c|c|}
\hline Variabel & Koefisien & Std. Error & T Stat. & Prob. \\
\hline $\mathrm{C}$ & 14425,019 & 3377,065 & 4,271 & 0,000 \\
\hline $\mathrm{X} 1$ & 249,257 & 127,000 & 1,963 & 0,056 \\
\hline $\mathrm{X} 2$ & $-1856,807$ & 467,713 & $-3,970$ & 0,000 \\
\hline $\mathrm{X} 3$ & 4,638 & 1,778 & 2,608 & 0,012 \\
\hline R-square & 0,874 & & & \\
\hline Adjusted R-Squared & 0,763 & & & \\
\hline F-Stat & 47,290 & & & \\
\hline Prob F-Stat & 0,000 & & & \\
\hline
\end{tabular}

Sumber: data olahan 2013

\section{Uji Signifikan Simultan (Uji Statistik F)}

Dari kesimpulan table diatas bisa diketahui bahwa secara simultan nilai F-hitung adalah 47,29 dan nilai F-tabel adalah 5,70 pada standar error 0,05 atau 5\%. Sehingga perbandingannya adalah F-hitung > F-tabel $(47,29>5,70)$. Ini berarti Ha diterima, bahwa terdapat pengaruh signifikan (Prob F-Stat $=0,00<\alpha=0,05$ ) secara simultan antara tingkat bunga, tingkat inflasi, earning per share(EPS), terhadap harga saham PT. Bank Mandiri (persero) Tbk 


\section{Uji Signifikan parameter individual/parsial (Uji Statistik t)}

Uji statistik t pada dasarnya menunjukkan seberapa jauh pengaruh satu variabel secara individual terhadap variabel independen. Hipotesis nol (Ho) yang diuji adalah apakah suatu parameter (bi) sama dengan nol:

1. Variabel Tingkat Inflasi (X1), dari hasil olah data di peroleh t-hitung adalah 1,963 dan t-tabel adalah 2,020. Dari perbandingan diketahui bahwa t-hitung < ttabel, sehingga $\mathrm{H}_{0}$ diterima dan disimpulkan tidak terdapat pengaruh signifikan dari tingkat Inflasi terhadap harga saham PT. Bank Mandiri (persero) Tbk. Perbandingan Prob t-stat juga $>$ dari $\alpha$ yaitu 0,056 .

2. Variabel Tingkat suku bunga (X2), dari hasil olah data di peroleh t-hitung adalah 3,970 dan t-tabel adalah 2,020. Dari perbandingan diketahui bahwa t-hitung $>\mathrm{t}-$ tabel, sehingga $\mathrm{H}_{\mathrm{a}}$ diterima dan disimpulkan terdapat pengaruh signifikan dari tingkat Suku Bunga terhadap harga saham PT. Bank Mandiri (persero) Tbk. Perbandingan Prob t-stat menunjukkan < dari $\alpha$ yaitu 0,00. Namun nilai koefisien untuk variabel X2 ini adalah negatif, sehingga pengaruhnya negatif.

3. Variabel Earning Per Share (X3), dari hasil olah data di peroleh t-hitung adalah 2,608 dan t-tabel adalah 2,020. Dari perbandingan diketahui bahwa t-hitung > ttabel, sehingga $\mathrm{H}_{\mathrm{a}}$ diterima dan disimpulkan terdapat pengaruh signifikan dari Earning Per Share terhadap harga saham PT. Bank Mandiri (persero) Tbk. Perbandingan Prob t-stat menunjukkan $<$ dari $\alpha$ yaitu 0,012 .

Dari hasil analisa data disimpulkan bahwa secara simultan ketiga faktor tersebut (Tingkat Inflasi, Tingkat Suku Bunga dan Earning Per Share) secara signifikan dan positif berpengaruh pada tingkat harga saham PT. Bank Mandiri (persero) Tbk. Pada bursa saham untuk periode analisa data tahun 2009 sampai dengan tahun 2012. Secara parsial, tingkat inflasi tidak berpengaruh. Periode tahun 2009 sampai dengan 2012, jika dilihat kembali data inflasi tersebut angka inflasi berada pada kisaran yang rendah dengan fluktuasi yang kecil. Kecuali pada awal tahun 2009, angka inflasi dimulai dari 9,17\% dan mengalami kecendrungan menurun sampai pada periode juni 2009 pada tingkat 3,65\%. Faktor tingkat suku bunga berpengaruh secara fignifikan, namun pengaruhnya negatif terhadap harga saham PT. Bank Mandiri (persero) Tbk. Faktor earning per share berpengaruh secara signifikan dan positif terhadap harga saham Bank Mandiri di bursa. Pertumbuhan EPS pertahun yang terus mengalami perbaikan ternyada dapat menarik para pelaku pasar untuk aktif dalam pembelian saham Bank Mandiri di Pasar, sehingga dapat mendorong peningkatan harga saham tersebut. 


\section{INTEGRA Volume III. Januari 2013. ISSN0216-4337}

\section{DAFTAR PUSTAKA}

Adler Haymans Manurung, 2003, Memahami Seluk Beluk Instrumen Investasi, PT. Adler Manurung Press, Jakarta.

Amit Malhotra, 2009, Factors Affecting Share Prices, EzineArticles.com.

Abdurrahman Sadikin, 2006, Pengaruh rasio - rasio Keuangan, Kurs, Tingkat Inflasi, dan Suku Bunga Deposito Terhadap Harga saham Perusahaan Manufaktur yang Terdaftar di Bursa Efek Jakarta, Jurnal JEPMA, Vol 5 No.1, Fekon UNLAM

Bodi, Kane, Marcus, 2006, Investment, The Mc Graw-Hill Companies, Inc.

Budi Bowonugraha, 2007, Analisa Pengaruh Variabel Fundamental dan Teknikal Terhadap Harga Saham Perbankan di BEJ, Tesis, Institut Teknologi Bandung.

Eugene F. Brigham, Joel F. Houston, 2006, Fundamentals of Financial Management, $10^{\text {th }}$ Edition, South- Western.

Eduardus Tandelilin, 2001, Analisa Investasi dan Manjemen Portofolio, Edisi Pertama, BPFE, Yogyakarta.

Iskandar Z. Alwi, 2003, Pasar Modal Teori dan Aplikasi, Nasindo Internusa, Jakarta.

James C. Van Horne, John M. Wachowicz, 2005, Fundamentals of Financial Management, $12^{\text {th }}$ Edition, Prentice - Hall Inc.

Mohamad Samsul, 2006, Pasar Modal dan Manajemen Portofolio, Erlangga, Jakarta.

Moeljadi, 2006, Manajemen Keuangan Pendekatan Kuantitatif dan Kualitatif, Edisi Pertama, Bayumedia Publishing, Malang

Nur Indiantoro dan Bambang Supomo, 2002, Metodologi Penelitian Bisnis untuk Akuntansi dan Manajemen, Edisi Pertama, BPFE, Yogyakarta.

Pandji Anoraga, Piji Pakarti, 2003, Pengantar pasar Modal, PT. Rineka Cipta, Jakarta.

Robert D. Mason, Douglas A. Lind, 1996, Statistical Techniques in Business and Economic, $9^{\text {th }}$ Edition, Richard D. Irwin. Inc,

Sugiyono, 2007, Metode Penelitian Bisnis, Alfabeta, Bandung.

Suharsimi Arikunto, 2000, Manajemen Penelitian, PT. Rineka Cipta, Jakarta

Singgih Santoso, 2005, Menggunakan SPSS untuk Statistik Parametrik, PT. Elek Media Komputindo, Jakarta.

Uma Sekaran, 2006, Research Metods for Business, John Willey \& Son Inc, New York.

http://www.bi.go.id/ 